\title{
LIQUID HYDROGEN TARGET EXPERIENCE AT SLAC
}

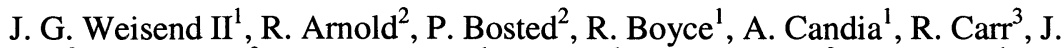 \\ $\mathrm{Gao}^{3}$, C. E. Jones ${ }^{3}$, W. Kaminskas ${ }^{1}$, J. Mark ${ }^{1}$, R. McKeown ${ }^{3}$, M. Racine ${ }^{1}$, S. \\ St Lorant ${ }^{1}, \mathrm{~T}$. Weber ${ }^{1}$ \\ ${ }^{1}$ Stanford Linear Accelerator Center \\ Menlo Park, CA 94025, USA \\ ${ }^{2}$ University of Massachusetts \\ Amherst, MA 01003, USA \\ ${ }^{3}$ California Institute of Technology \\ Pasadena, CA 91125, USA
}

\begin{abstract}
Liquid hydrogen targets have played a vital role in the physics program at SLAC for the past 40 years. These targets have ranged from small "beer can" targets to the $1.5 \mathrm{~m}$ long E158 target that was capable of absorbing up to $800 \mathrm{~W}$ without any significant density changes. Successful use of these targets has required the development of thin-wall designs, liquid hydrogen pumps, remote positioning and alignment systems, safety systems, control and data acquisition systems, cryogenic cooling circuits and heat exchangers. Detailed operating procedures have been created to ensure safety and operational reliability.

This paper surveys the evolution of liquid hydrogen targets at SLAC and discusses advances in several of the enabling technologies that made these targets possible.
\end{abstract}

KEYWORDS: Liquid Hydrogen, Targets, High Energy Physics.

PACS: 29.25Pj, 07.20Mc

\section{INTRODUCTION}

Liquid hydrogen $\left(\mathrm{LH}_{2}\right)$ targets have been an important part of the SLAC research program from the founding of the laboratory in 1964 until the most recent target experiment completed in 2003. The value of hydrogen as a target material is that it provides a source of electrons that the incoming electron beam can be scattered off of, without the presence of neutrons that can add unwanted background signals to the 
experiment. Liquid hydrogen is particularly desirable as its higher density results in more scattering interactions and thus more experimental data. SLAC has operated multiple beam lines simultaneously and at times up to four of them have had $\mathrm{LH}_{2}$ targets at the same time. More than $30 \mathrm{LH}_{2}$ targets have been run at SLAC. TABLE 1 is a representative list of SLAC $\mathrm{LH}_{2}$ targets.

Target requirements varied from experiment to experiment but generally included: minimization of beam interaction with the target structure compared to interaction with the $\mathrm{LH}_{2}$, removal of deposited heat to prevent boiling or significant density changes of the hydrogen, ability to move the target out of the beam line or to operate an empty target, maintenance of proper alignment of the target relative to the beam and reliable around the clock operation. Successful use of $\mathrm{LH}_{2}$ targets has required the development of thin walled leak tight structures, cryogenic cooling techniques, pumps, controls and alignment systems and safety systems.

\section{TYPES OF TARGETS}

Broadly speaking, $\mathrm{LH}_{2}$ targets at SLAC may be divided into 2 categories: secondary beam targets and primary beam targets. Secondary beam targets are exposed not to the full electron beam of the SLAC linac but rather to a scattered portion of that beam. These targets are generally smaller, absorb less beam energy and thus require simpler cooling schemes. Primary beam targets interact directly with the primary electron beam. These targets are generally larger, absorb more beam power and frequently require more sophisticated cooled schemes such as dedicated helium refrigerators and forced flow circulation of the liquid hydrogen. Secondary beam targets were the first used at SLAC and thus will be discussed first.

\section{Secondary Beam Targets}

FIGURE 1 is a schematic of a typical secondary beam target. The hydrogen is gravity fed from a reservoir. This reservoir is itself refilled by liquid hydrogen purchased by SLAC and transported in trailers. These targets were supplied by the reservoir from tubing that entered a low point in the target. A vent back to the gas space in the reservoir could be closed, causing the target to empty back into the reservoir for an "empty target" calibration. The targets operated at atmospheric pressure and could only absorb a limited amount of heat before significant changes in hydrogen density occurred. The targets were constructed from Mylar. Fabricating the Mylar targets was something of an art that depended considerably on the skill of the individual doing the assembly. The adhesive of choice was usually Shell 820 or Shell 815 with Versamid 125 catalyst. The ratio of resin to catalyst would determine the properties of the cured resin. Joints in the Mylar were prepared by abrading them with a light sandblasting or wet blasting. A number of techniques were developed for forming heads. To form a Mylar head, a sheet of Mylar was formed between two $0.381-\mathrm{mm}$ copper sheets. In order to form properly, the copper had to be half hard or softer. After forming, the formed assembly had to be heated warm enough to anneal the Mylar so that it would retain its shape. Developing punches and dyes to form these heads also became something of an art.

Separating the copper-Mylar-copper sandwich could be done if a small hole was in the center of the copper disks. Air or water pressure could be used to separate the sheets. On sizes too small for that to work, the copper could be chemically removed with nitric acid. 
TABLE 1. Examples of SLAC $\mathrm{LH}_{2}$ targets.

\begin{tabular}{|c|c|c|c|c|c|}
\hline $\begin{array}{l}\text { Experiment } \\
\text { No. }\end{array}$ & Target Characteristics & $\begin{array}{c}\text { Beam } \\
\text { Characteristics }\end{array}$ & $\begin{array}{c}\text { Target cell } \\
\text { material }\end{array}$ & Cooling & Ref \\
\hline Test beams & $\begin{array}{l}\text { First target in a family with } \\
\text { horizontal cells, up to } 1.98- \\
\mathrm{m} \text { m long, } 178-\mathrm{mm} \\
\text { diameter. }\end{array}$ & $\begin{array}{l}\text { Secondary } \\
\text { beams (Mu } \\
\text { meson) }\end{array}$ & Mylar & $\begin{array}{l}\text { Direct } \\
\text { cooling by } \\
\text { convection } \\
\text { in target. } \\
\end{array}$ & 1 \\
\hline $\begin{array}{l}\text { E } 007 \\
\text { E } 021 \\
\text { E } 022\end{array}$ & $\begin{array}{l}\text { A family of targets with } \\
\text { horizontal or vertical cells. } \\
\text { Vertical cell: } 304.8-\mathrm{mm} \\
\text { diameter, horizontal cells: } \\
\text { typically } 381-\mathrm{mm} \text { long, } \\
50.8-\mathrm{mm} \text { to } 88.9-\mathrm{mm} \text { Dia. }\end{array}$ & $\begin{array}{l}\text { Primary } \\
\text { electron beam } \\
\text { typically } 4.3 \text { to } \\
8 \mathrm{GeV} \text { at } 10 \mu \mathrm{A}\end{array}$ & $\begin{array}{l}\text { Vertical } \\
\text { cells: Al, } \\
\text { Ni, SS } \\
\text { Horizontal } \\
\text { cells: Mylar }\end{array}$ & $\begin{array}{l}\text { Natural } \\
\text { Convection } \\
\text { with heat } \\
\text { exchanger. }\end{array}$ & $\begin{array}{l}2,3, \\
4,5 \\
6\end{array}$ \\
\hline $\begin{array}{l}\text { E } 050 \\
\text { E } 052 \\
\text { E } 057\end{array}$ & $\begin{array}{l}\text { Condensation target family } \\
\text { (5) with vertical geometry. } \\
\text { Cell diameters from } 80 \text { to } \\
320 \mathrm{~mm} \text {. }\end{array}$ & $\begin{array}{l}\text { Primary } \\
\text { electron beam }\end{array}$ & $\begin{array}{l}\text { Stainless } \\
\text { steel }\end{array}$ & $\begin{array}{l}\text { Forced } \\
\text { convection } \\
\text { with vane- } \\
\text { axial fan. }\end{array}$ & $\begin{array}{l}7 \\
8 \\
9\end{array}$ \\
\hline $\begin{array}{l}\text { E } 004 \\
\text { E } 073\end{array}$ & $\begin{array}{l}\text { Family of cells } \\
\text { characterized by a vertical } \\
\text { geometry, } 76.2-\mathrm{mm} \text { Dia. } \\
\text { 38.1-mm high. }\end{array}$ & $\begin{array}{l}\text { Primary } \\
\text { electron beam }\end{array}$ & Aluminum & $\begin{array}{l}\text { Forced } \\
\text { convection } \\
\text { with vane- } \\
\text { axial fan. }\end{array}$ & $\begin{array}{l}10 \\
11 \\
12\end{array}$ \\
\hline E 089 & $\begin{array}{l}\text { Family of cells } 88.9-\mathrm{mm} \\
\text { Dia., 152- and } 304-\mathrm{mm} \\
\text { long. }\end{array}$ & $\begin{array}{l}\text { Primary } \\
\text { electron beam }\end{array}$ & Aluminum & $\begin{array}{l}\text { Forced } \\
\text { convection } \\
\text { with vane- } \\
\text { axial fan. }\end{array}$ & 13 \\
\hline $\begin{array}{l}\text { Streamer } \\
\text { Chamber } \\
\text { E } 072 \\
\text { E } 104\end{array}$ & $\begin{array}{l}\text { Length: } 460 \mathrm{~mm} \text {, Dia. } 8 \\
\mathrm{~mm} \text {, inside } 10-\mathrm{mm} \text { ID Mylar } \\
\text { tube vacuum jacket }\end{array}$ & $\begin{array}{l}\text { Secondary mu } \\
\text { meson and } \\
\text { photon beams }\end{array}$ & $\begin{array}{l}\text { Tape } \\
\text { wound } \\
\text { Mylar straw }\end{array}$ & $\begin{array}{l}\text { Forced } \\
\text { Convection }\end{array}$ & $\begin{array}{l}14, \\
15, \\
16, \\
17\end{array}$ \\
\hline $\begin{array}{l}\text { LASS } \\
\text { E } 127 \\
\text { E } 132\end{array}$ & $\begin{array}{l}\text { Length: } 851 \text { mm, Dia: } 54 \\
\text { mm }\end{array}$ & $\begin{array}{l}\text { Secondary } \mathrm{K} \\
\text { meson beam }\end{array}$ & Mylar & $\begin{array}{l}\text { Subcooled } \\
\mathrm{LH}_{2} \text { cooling } \\
\text { provided by } \\
\mathrm{CTI} 1400 \mathrm{He} \\
\text { refrigerator }\end{array}$ & $\begin{array}{l}18 \\
19 \\
20 \\
21\end{array}$ \\
\hline $\begin{array}{l}\text { E } 136 \\
\text { E } 139\end{array}$ & $\begin{array}{l}\text { High power target system } \\
\text { of four cells. Each cell } \\
\text { consists of concentric Mylar } \\
\text { cylinders: two cells are } 650- \\
\mathrm{mm} \text { long, two cells are } 250- \\
\mathrm{mm} \text { long. The diameters of } \\
\text { the inner and outer tubes } \\
\text { are the same: } 49.5 \text { and } \\
66.5 \mathrm{~mm} \text {, respectively. }\end{array}$ & $\begin{array}{l}\text { Primary } \\
\text { electron beam, } \\
8 \text { to } 24.5 \mathrm{GeV} \text {, } \\
4 \times 10^{11} \\
\text { electrons pp at } \\
180 \text { pps }\end{array}$ & $\begin{array}{l}\text { Concentric } \\
\text { Mylar } \\
\text { cylinders, } \\
\text { inner } 0.05 \\
\mathrm{~mm} \text { thick, } \\
\text { outer } 0.254 \\
\mathrm{~mm} \text { thick }\end{array}$ & $\begin{array}{l}\text { Fan-forced } \\
\text { flow cooling } \\
\text { through } \\
\text { common } \\
\text { heat } \\
\text { exchanger } \\
\text { for both } \\
\text { short and } \\
\text { long cells. } \\
\end{array}$ & $\begin{array}{l}22 \\
\text { to } \\
27\end{array}$ \\
\hline $\begin{array}{l}\text { NPAS } \\
\text { NE } 04 \\
\text { NE } 11 \\
\text { NE } 18 \\
\end{array}$ & $\begin{array}{l}\text { High power target system } \\
\text { of multiple cells. The cells } \\
\text { varied in length from } 150 \text { to } \\
250 \text {-mm "Beer can" targets. }\end{array}$ & $\begin{array}{l}\text { Primary } \\
\text { electron beam }\end{array}$ & Aluminum & $\begin{array}{l}\text { Fan-forced } \\
\text { flow cooling }\end{array}$ & $\begin{array}{l}28 \\
\text { to } \\
34\end{array}$ \\
\hline E158 & $\begin{array}{l}\text { High power }(1 \mathrm{~kW}) \text { target. } \\
1.5-\mathrm{m} \text { long by } 76.2 \mathrm{~mm} \text { in } \\
\text { length }\end{array}$ & $\begin{array}{l}\text { Primary } \\
\text { electron beam }\end{array}$ & $\begin{array}{l}\text { Aluminum } \\
\& S S\end{array}$ & $\begin{array}{l}\text { Forced } \\
\text { convection } \\
\text { Subcooled } \\
\mathrm{LH}_{2} \text { cooling } \\
\text { provided by } \\
\mathrm{CTI} 4000 \mathrm{He} \\
\text { refrigerator } \\
\end{array}$ & 35 \\
\hline
\end{tabular}




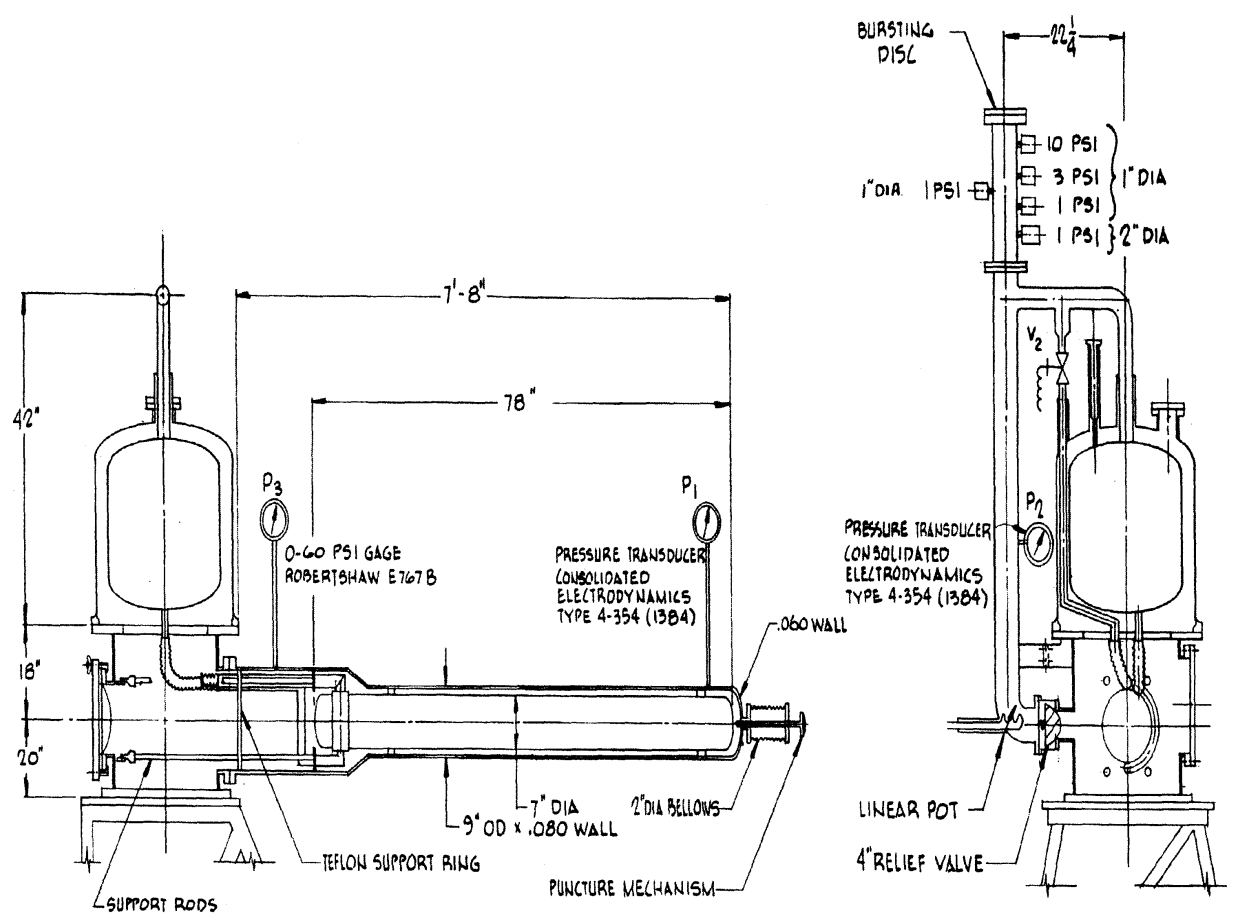

FIGURE 1. Typical secondary beam target [1].

\section{Primary Beam Targets}

Targets operated in the primary electron beam had to be more sophisticated to deal with the greatly increased heat load from the beam. The targets were generally constructed from thin-walled stainless steel. In order to absorb the higher heat load without significant density changes the target design had the reservoir separated from the target cell via a heat exchanger. This allowed the targets to be operated at higher than atmospheric pressure (typically at about $35 \mathrm{psia}$ ) which resulted in roughly $3 \mathrm{~K}$ of subcooling. FIGURE 2 shows a schematic of a typical primary-beam target. In this design, gaseous hydrogen or deuterium is condensed in the target cell via heat transfer from the heat exchanger linking the cell to the upper hydrogen reservoir. Note in FIGURE 2 the dummy target cell that can be moved into the beam line to allow an empty target calibration.

Increased beam heating could be tolerated by designing the target system to optimize natural convention heat transfer between the hydrogen in the target cell and the heat exchanger or by the use of mechanical pumps to force flow the hydrogen through the heat exchanger. This last method drove the development of liquid hydrogen pumps described below.

\section{ENABLING TECHNOLOGIES FOR LH2 TARGETS}

\section{Liquid Hydrogen Pumps}

One of the principal requirements of liquid hydrogen targets is that any heating by the electron beam or by static heat leak not significantly alter the density of the liquid. Even 


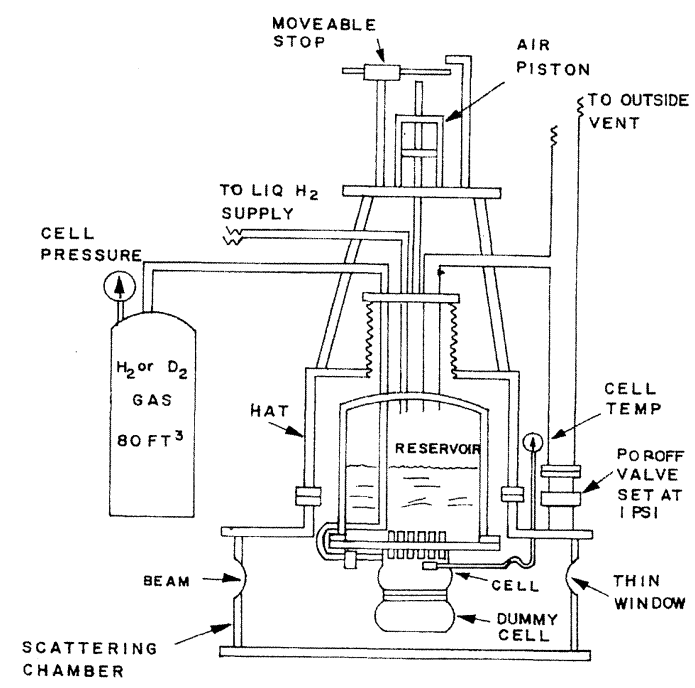

FIGURE 2. Typical primary-beam target [2].

small density alterations may add unwanted background signals to the experimental data. When the heat load to the target is too high to be dealt with by natural-convection cooling without unacceptable density changes, then forced-flow cooling driven by hydrogen pumps becomes necessary. SLAC has developed or adapted many versions of hydrogen pumps to meet target needs. These include centrifugal pumps, positive-displacement pumps (both bellows and piston) and vane-axial fans. Pump motors have been both submerged in the liquid hydrogen and operated at room temperature.

Some of these pump designs have been adapted for use in experiments run outside of SLAC such as the SAMPLE experiment at MIT and the G0 Experiment at Jefferson Lab.

FIGURE 3 shows a two-stage vane-axial fan used to provide cooling for the E136 target[32]. This pump is an adaptation of a Globe VAX 4.5 pump with SLAC designed housing and impellers. The resulting fan is capable of pumping 6 liters per second of liquid

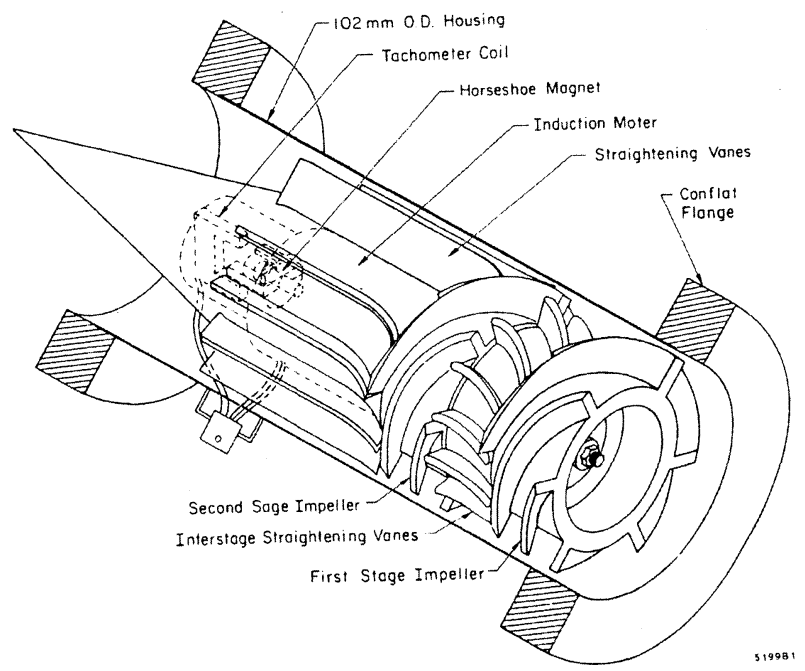

FIGURE 3. Two stage axial vane fan used in E136 [23]. 


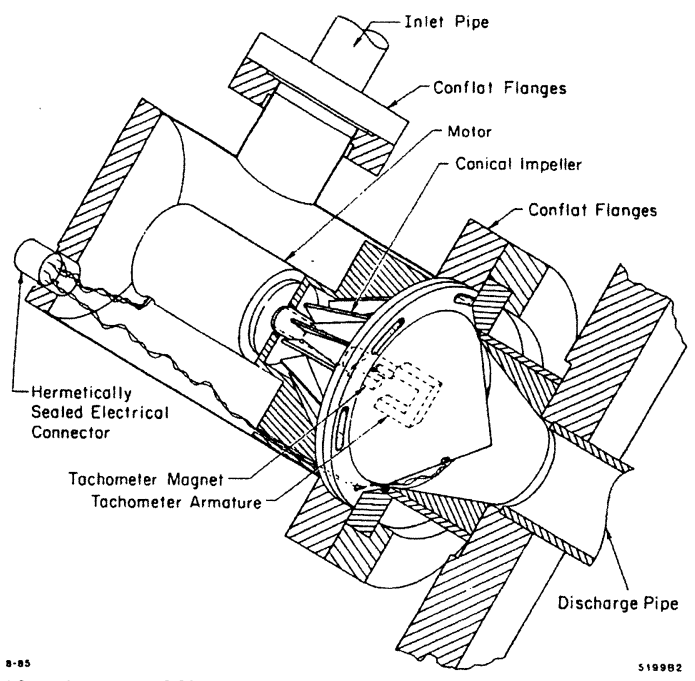

FIGURE 4. SLAC centrifugal pump [23].

hydrogen with a total head of 2 meters. The motor is submersed in the $\mathrm{LH}_{2}$ and is a 3-phase 4-pole induction motor which drives the $100-\mathrm{mm}$ diameter fan blades at up to $30 \mathrm{~Hz}$. The heat generated by the motor is inconsequential compared to the up to $300 \mathrm{~W}$ deposited by the beam into the hydrogen. Note the straightening vanes between the 2 stages. These help increase the over all head of the pump by straightening out the swirl in the fluid before the second stage. This pump was also operated in liquid Deuterium.

FIGURE 4 shows a centrifugal pump developed by SLAC to replace a vane-axial fan in an existing target. The existing fan would not provide sufficient circulation to compensate for increased beam heating in a new experimental program. This pump had a maximum flow rate of 3 liters per second with a $10-\mathrm{m}$ head and operates at $50 \mathrm{~Hz}$. Again the motor was submerged in the liquid hydrogen.

A double-acting bellows pump is shown in FIGURE 5. This produced a flow rate of up to 2 liters per minute for circulating the $\mathrm{LH}_{2}$ in the streamer chamber target (see below). This pump generated up to $12-\mathrm{m}$ of head. The pump was actuated by a room temperature air cylinder mechanically linked to the cold bellows.

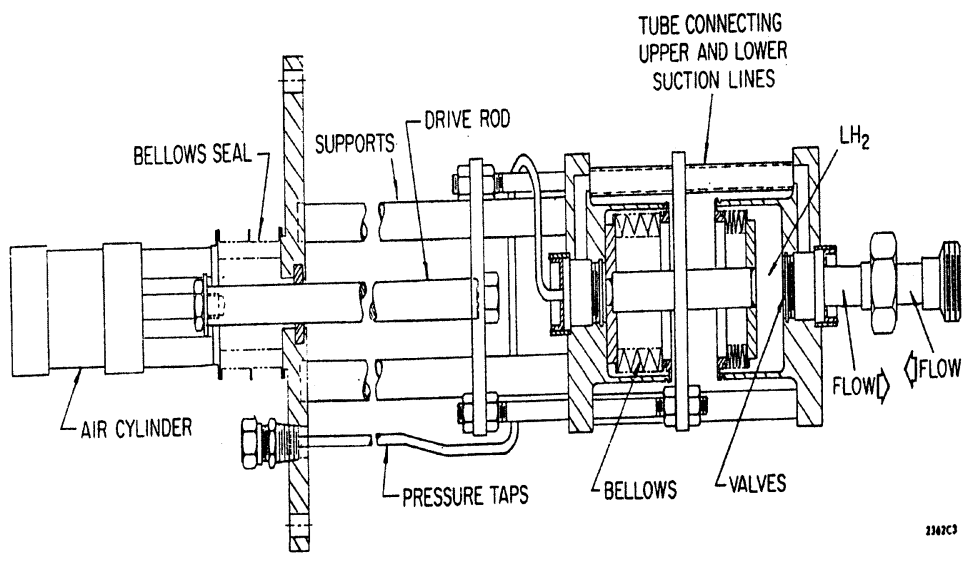

FIGURE 5. Double-acting bellows pump [37]. 
A double-acting piston pump was constructed and tested as a development project. This pump was driven by the same air cylinder as the bellows pump and used a 63.5-mm diameter piston. The cryogenic sliding seals on the piston were graphite-filled Teflon seals. This pump was operated continuously for 30 days without any problems or unusual wear.

The last hydrogen pump operated at SLAC was a large two stage vane-axial pump developed for the E158 experiment [35]. This pump was designed and built at Caltech based on the SAMPLE pump, which itself evolved from the vane-axial hydrogen pumps at SLAC. The E158 pump used a room-temperature motor that was immersed in the warmhydrogen gas space. The fans were connected to the motor by a long hollow shaft which was supported by bearings at room temperature and at $18 \mathrm{~K}$. The pump ran at $15 \mathrm{~Hz}$ and generated a flow rate of $1.5 \mathrm{~kg} / \mathrm{s}$ resulting in a velocity of $5 \mathrm{~m} / \mathrm{s}$ in the target. This pump ran very well for several months but did fail due to a seemingly minor design change coupled with an assembly error. After these problems were corrected and the pump rebuilt, it operated flawlessly for the remainder of the experiment.

\section{Cooling Schemes}

Small, secondary-beam targets that absorbed low amounts of energy were operated in saturated- $\mathrm{LH}_{2}$ baths (FIGURE 1). The majority of primary-beam hydrogen targets used pressurized $\mathrm{LH}_{2}$ in the target cell cooled via natural or forced convection with a heat exchanger linking the tank cell with an upper saturated-LH $\mathrm{H}_{2}$ bath (FIGURE 2).

These saturated baths were in turn filled by $\mathrm{LH}_{2}$ provided by trailer or by a large dewar located near the experimental hall. In experiments carried out in End Station A the distance from the trailers or dewar to the upper reservoir was $\sim 50 \mathrm{~m}$. A major challenge in target operation was the refilling of the upper saturated- $\mathrm{LH}_{2}$ bath without disrupting the target. Initially, the transfer line from the trailer or dewar had to be cooled down at the start of each transfer. Warm gas from this cool down process would enter the upper reservoir and boil off some of the $\mathrm{LH}_{2}$. This problem was solved by the design and construction of a quad-axial transfer line that connected the upper target reservoir with the storage dewar. In this line, the gas boiling off the upper reservoir flows through a vacuum-insulated annular space. In the center of the line, also vacuum insulated from the annular space, is the line that brings the $\mathrm{LH}_{2}$ from the storage dewar to the upper reservoir. In this design the inner line always stays cold and fills take place with minimum disruption to the target. The situation was further improved by adding a proportional valve and control system to allow the filling to be continuous rather than batch. This also served to reduce the workload of the cryogenic technicians.

In two $\mathrm{LH}_{2}$ experiments, the target was cooled not by heat transfer to a saturated $\mathrm{LH}_{2}$ bath but rather to a helium refrigeration plant. In the case of the LASS target, the cooling was provided by a CTI 1400 refrigerator with a capacity of $75 \mathrm{~W}$ at $20 \mathrm{~K}$. The last target operated at SLAC, the E158 target, was cooled by a Sulzer/CTI 4000 refrigerator with a capacity of $\sim 1200 \mathrm{~W}$ at $16 \mathrm{~K}$. This target was routinely operated with a heat load of $800 \mathrm{~W}$ without difficulty. The cryogenic system for the E158 target is described in reference [38].

\section{Safety Systems}

The flammability of hydrogen dictated careful attention to safety. Targets were reviewed by SLAC safety committees before being allowed to operate. Target systems at SLAC were designed to avoid both the mixing of hydrogen and air in the experimental hall and the presence of ignition sources. All targets were vented outside the halls into open air away from ignition sources. Smaller targets were surrounded by a fireproof tent designed to 
collect and vent outside any hydrogen in the event of a target failure. The scattering chambers of larger targets were designed to contain any released hydrogen and vent it outside. Detailed procedures were written to prevent the mixing of air and hydrogen during target operations. As a backup, hazardous atmosphere detection systems were installed to detect the presence of hydrogen leaks. These systems sounded evacuation alarms and notified the fire department. The large $(501)$ volume of $\mathrm{LH}_{2}$ in the E158 target required additional safety measures [39].

\section{EXAMPLES OF TARGETS}

\section{E136 Target}

FIGURE 6 shows the E136 hydrogen target [36]. This is a fairly typical high-power target system. The experiment required two different length hydrogen targets through which the beam transited axially. Two empty targets of the same length were included for calibration purposes. This entire assembly could be remotely raised and lowered to bring any of the four target cells into line with the beam. Up to $225 \mathrm{~W}$ were deposited into the $\mathrm{LH}_{2}$ by the beam. To avoid density changes, the hydrogen in both cells was circulated by a vane axial fan through a heat exchanger and kept subcooled.

\section{“Beer Can" Targets}

Usually targets were designed to have the minimum amount of metal in the primary beam and the scattered beam. One technique used for minimizing material was to use a one-piece shell and head instead of a cylinder with a head attached to it. Coors ${ }^{\circledR}$ Beer Company supplied SLAC with a generous quantity of blanks for their 16-ounce beer can. With special punches and dies, the flat end of these can blanks were formed to a toruspherical shape. To further reduce the material in the head, chemical milling was used to reduce the thickness from about $0.1524 \mathrm{~mm}$ to $0.0762 \mathrm{~mm}$. This process depended completely on the skill and patience of the technician. It was also dependent on the concentration and temperature of the sodium hydroxide solution doing the milling. Fairly uniform results were obtained if the dome just touched the solution and capillary action
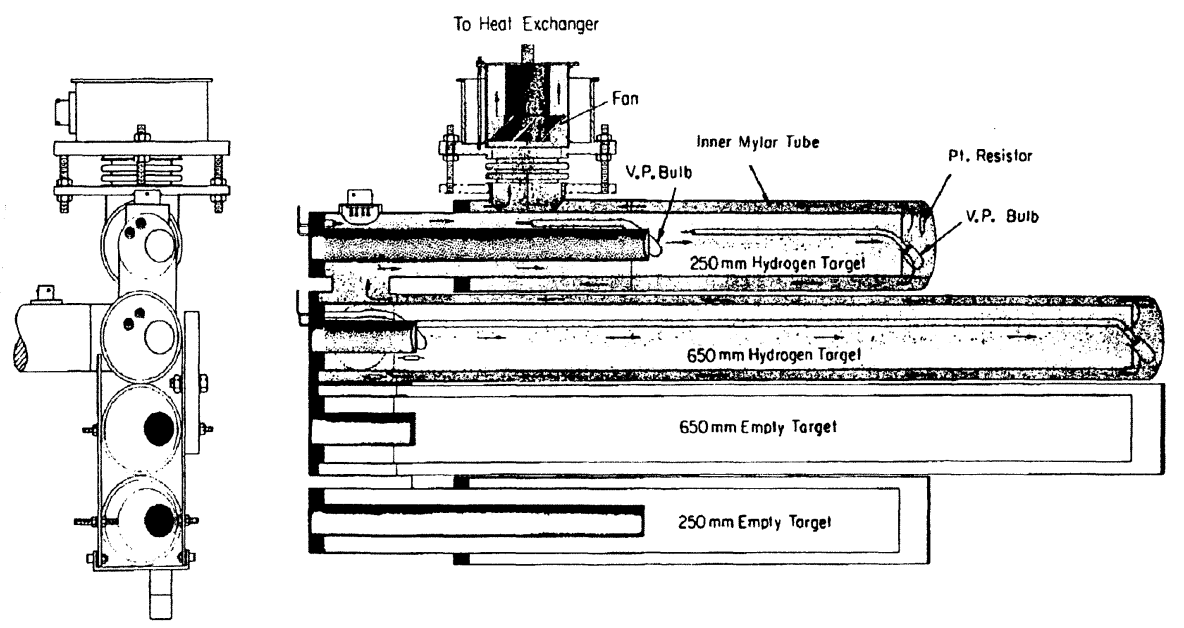

FIGURE 6. E136 target [36]. 


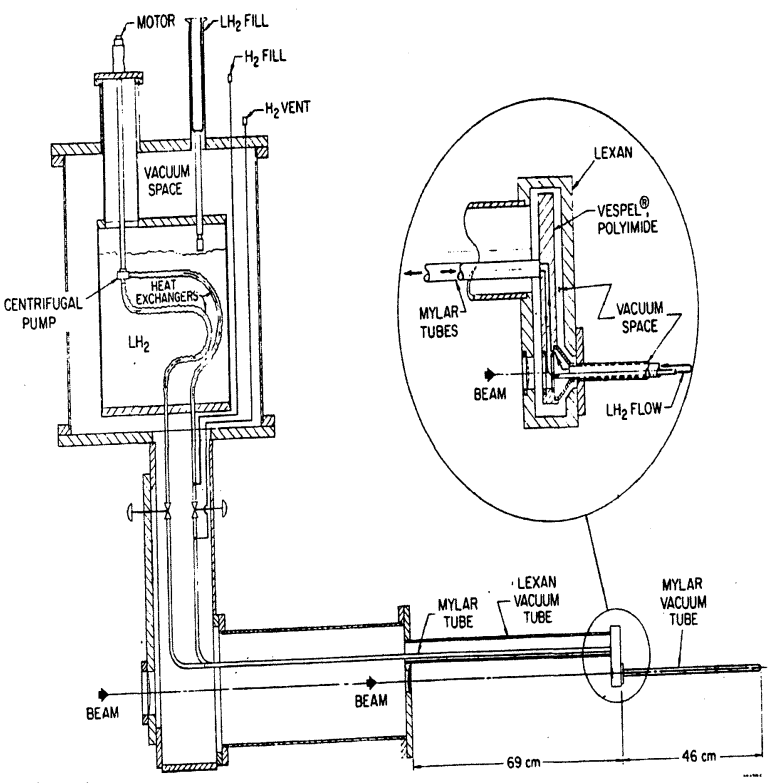

FIGURE 7. Streamer chamber target [34].

carried it out to the edges. Special measuring tools were required to monitor the amount of material removed.

\section{Streamer Tube Target}

A liquid hydrogen target was required for studies conducted inside the SLAC 2-m streamer chamber [37]. The target operated between the electrodes of the streamer chamber was pulsed $+/-600 \mathrm{kV}$. This meant that no conductive material could be used for the target. The solution was to construct the target from a Mylar straw, $8 \mathrm{~mm}$ in diameter by $460-\mathrm{mm}$ long. This target was contained inside a 10-mm ID Mylar tube which acted as the vacuum jacket, isolating the target from the room-temperature streamer tube. In front of the target tube, a larger diameter Mylar tube inside a Lexan tube connected the target to an upper reservoir of saturated $\mathrm{LH}_{2}$. Proper functioning of the target required that no bubbles be present in the $\mathrm{LH}_{2}$. This in turn necessitated that the hydrogen in the target be circulated by a pump and cooled via the upper bath of $\mathrm{LH}_{2}$. FIGURE 7 shows the streamer chamber target assembly. Initially circulation was provided by a centrifugal pump but this was later replaced with a double-acting bellows pump.

\section{SUMMARY}

$\mathrm{LH}_{2}$ targets have a long history at SLAC. The successful use of these targets required innovations in materials, pump technology, cooling, safety systems and controls.

\section{ACKNOWLEDGEMENTS}

The authors would like to thank all the technicians, engineers, students and physicists that have made the SLAC target program successful over the years. Work supported by the U.S. Department of Energy under contract number DE-AC02-76SF00515. 


\section{REFERENCES}

1. Clay, H. and Cheng, D., "MU BEAM LH(2) Target System," SLAC-TN-67-1, Feb. 1967, 17 pp., unpublished.

2. Anderson, R. L., "SLAC High Power Hydrogen Target," Nucl.Instrum.Meth. 70, pp. 87-89 (1969).

3. Anderson, R. L., et al., Phys. Rev. Lett. 21, pp. 479-481 (1968).

4. Anderson, R. L., et al., Phys. Rev. Let. 21 pp. 384-386 (1968).

5. Anderson, R. L., et al., Phys. Rev. Let. 23 pp. 890-892 (1969).

6. Anderson, R. L., et al., Phys. Rev D1 21 pp. 27-47 (1970).

7. Coward, D. H., et al, Phys. Rev. Lett. 20 pp.292-295 (1968).

8. Bloom, E. D., et al., Phys. Rev. Lett. 23 pp. 930-934 (1969).

9. Kirk, P. N., et al., Phys. Rev. D8, pp. 63-91 (1973).

10. Bell, R., "A Liquid Hydrogen Target for SLAC's 30-MA Electron Beam,” in IEEE Trans. Nucl. Sci. 16, 1969, pI 631-632.

11. Miller, G., et al., Phys. Rev. D 5 p. 528 (1972).

12. Mark, J. and Pierce, W., "Hydrogen Targets at SLAC," in IEEE Trans. Nucl. Sci. 18 1971, p. 806.

13. Rochester, L.S., et al., Phys.Rev.Letters 36 p. 1284 (1976), Erratum-ibid. 37, p. 233 (1976).

14. Mark, J., "Liquid Hydrogen Pumping for Hydrogen Targets," in Advances in Cryogenic Engineering 19, edited $\mathrm{t}$ D. Timmerhaus, Plenum, New York 1974, pp. 248-252.

15. Mozley, R. F., “Muon Proton Scattering,” Lepton-Photon Symp, 1975, p. 783.

16. del Papa, C., et al., Phys. Rev. D 13, p. 2934 (1976).

17. del Papa, C., et al., Phys. Rev. D 15, p. 2425 (1977).

18. Gilchriese, M. G. D., et al., Phys. Rev. Letters 40 p. 6 (1978).

19. Stroynowski, R., et al., Phys. Lett. B 97 p. 315 (1980).

20. Aston, D., et al., Phys. Lett. B 99 p. 502 (1981).

21. Blockus D., et al., Nucl. Phys. B pp. 201-205 (1982).

22. Mark, J., “A 650-Mm Long Liquid Hydrogen Target For Use In A High Intensity Electron Beam,” in Advances in Cryogenic Engineering 29, edited by R. W. Fast, Plenum, New York 1984, pp. 1033-1039.

23. Mark, J., "Submersible Fans and Pumps for Cryogenic Fluids," in Advances in Cryogenic Engineering 31, editer R. W. Fast, Plenum, New York 1985, pp. 999-1006.

24. Arnold, R., et al, Phys. Rev. Lett. 57, p. 174 (1986).

25. Sill, A. F., et al., Phys. Rev. D 48, pp.29-55 (1993).

26. Gomez, J., et al, Phys. Rev. D 49, pp.4348-4372 (1994).

27. Bosted, P., et al, Phys. Rev. D 49, pp. 3091-3097 (1994).

28. Arnold, R. G., et al, Phys. Rev. C 42, pp. 1-5 (1990).

29. Bosted, P., et al, Phys. Rev. C 42, pp. 38-64 (1990).

30. Bosted, P., et al, Phys. Rev.C 46, pp. 2505-2515 (19920.

31. Lung, A., et al, Phys. Rev. Lett. 70, pp.718-721 (1993).

32. Frodyma, M., et al, Phys. Rev. C 47, pp. 1599-1614 (1993).

33. Andivahis, L, et al, Phys. Rev. D 50, pp. $5491-5517$ (1994).

34. Arrington, J., et al, Phys. Rev. C 53, pp. 2248-2251 (1996).

35. Gao, J., et al., Nucl.Instrum.Meth.A 498, pp. 90-100 (2003).

36. Mark, J., "A 650-Mm Long Liquid Hydrogen Target For Use In A High Intensity Electron Beam," in Advances in Cryogenic Engineering 29, edited by R. W. Fast, Plenum, New York 1984, pp. 1033-1039.

37. Mark, J., "Liquid Hydrogen Pumping For Hydrogen Targets," SLAC-PUB-1287 (1973), 12 pp.

38. Weisend II, J. G., et al., "The Cryogenic System for the SLAC E158 Experiment," in Advances in Cryogenic Engineering 47, edited by Susan Breon, et al., AIP Conference Proceedings Vol. 613, New York 2000, pp. 171-179.

39. Weisend II, J. G., et al., "Safety Aspects of the E158 Liquid Hydrogen Target System," in Proceedings of the Nineteenth International Cryogenic Engineering Conference ICEC 19, edited by P. Seyfert, New York 2003, pp. 605-608. 